\title{
Phytochemical Screening of Antimicrobials from Allium cepa
}

\author{
Hiral A Gadhavi ${ }^{1}$, Dr. Himanshu Pandya ${ }^{2}$ \\ ${ }^{1}$ Research Scholar, Department of Botany, Gujarat University, Ahmedabad, India \\ ${ }^{2}$ Professor, Department of Botany, Gujarat University, Ahmedabad, India
}

\begin{abstract}
Allium cepa belongs to family Apiaceae, is a hebaceous annual plant spread throuout India. It is commonly known Onion or Pyaz in India. The present study renders the preliminary phytochemical screening and antimicrobial activity of Allium cepa. In the present study two bacteria were tested for their antimicrobial susceptibility against Petrolum ether, Acetone and Methanolic extract of plant. The antimicrobial activity of plant extracts were assayed using well diffusion method. The results showed alkaloids, flavnoids, steroids, phenols, amino acids, glycosides, tannins triterpanoids and carbohydrates are present different extracts. Antimicrobial effects of methanolic extract show the highest inhibition against E.coli and B.Subtilis. Acetone extract shows minimum Inhibitory effect against E.coli and B.Subtilis. This study provides evidence for the presence of one or more soluble constituents in the plants used, that probably interferes with bacterial growth and their metabolism which would prevent and inhibit initiation and progression of many diseases
\end{abstract}

Keywords: Allium cepa, Phtochemical screening, Antibacterial Activity.

\section{Introduction}

Since ancient time, people have been exploring the nature particularly the plants in search of new drugs. This has resulted in the use of large number of medicinal plants with curative properties to treat various diseases [13].The medicinal plants contain some active organic compounds which provide physiological action in human body. They are called Phytochemicals [4].

The most important of these bioactive constituents in plants are alkaloids, tannins, flavonoids, carbohydrates, terpenoids and steroids [7]. These compounds are synthesized by primary or rather than secondary metabolism of living organism. Secondary metabolites are chemically or taxonomically extremely diverse compounds with obscure function. They are widely used in human therapy, veterinary, agriculture and scientific research and countless other areas [8].

Interest in the antimicrobial properties of active compound is strengthened by the findings that they affect the behavior of pathogenic bacteria or fungi of agro-food or medical field. Indeed their use as natural additives in food industry is increased in recent years [3]. Onion is the second most important vegetable worldwide next to tomatoes. Among all varieties of onion Asian white onions have the most eye irritating chemical reaction [10].

Onions is the richest source of flavonoids and organosulphur compounds. It is used as an important source of phytoconstituents and food flavor [5]. Onion is rich source of flavonoids, polyphenols, organic sulpur, saponins and many other secondary metabolites, which are mainly responsible for its medicinal activities. It contains Kampferol, $\beta$-sitosterol, ferulic acid, myritic acid and prostaglandins [10].

Onion is indispensable item in every kitchen as good condiment. It is also used in the form of pickles, dehydrated powder and flakes. The onion is also an export oriented crop earning valuable foreign exchange for our country India. Some varieties of onions were found to contain an array of antifungal compounds that can serve as templates for future fungicides. Onion is one of the commonly used vegetable in all dishes and salads in daily life [2].

Preliminary studies have shown increased consumption of onion reduces the risk of head and neck cancer. Traditionally onion has been used to treat intestinal infection [10]. The plant Allium cepa Linn are proved too shown the antidiabetic, antioxidant, antihypertensive, antithrombotic, hypoglycemic, anti-hyperlipidemic activity. They contain chemical compounds believed to have anti inflammatory, anti cholesterol, anti cancer and antioxidant properties such as quercentin.

\section{Materials and Methods}

\subsection{Preliminary Phytochemical Screening}

All most all the plant parts were used for preliminary phytochemical screening. The plant material was washed thoroughly, dried under the open shade, ground and stored in paper bags at room temperature. These plant samples were screened to detect different phytochemicals.

$2 \mathrm{ml}$ of each extract was measured into a test tube for each of the tests and concentrated by evaporating the extractant in a trough. Tests were carried out for carbohydrates, reducing sugars, tannins, phenols, flavonoids, alkaloids, steroids, glycosides and triterpenoids. The screening was carried out in the Department of Botany of the Gujarat University, Gujarat, India. Preliminary phytochemical screening of plant was done according to the standard procedures adopted by the various workers [11], [1], [12], [6], [14].

\subsection{Antimicrobial activity}

1) Extraction of plant material

Plant extracts were prepared by cold extraction method [6]. 


\section{International Journal of Science and Research (IJSR) \\ ISSN (Online): 2319-7064}

Index Copernicus Value (2015): 78.96 | Impact Factor (2015): 6.391

Cold extraction was done in organic solvents respectively to get the crude extract.

\section{2) Solvent extraction}

$10 \mathrm{~g}$ dried and fine powdered material was suspended in 100 $\mathrm{ml}$ of Petroleum ether/ Acetone/ Methanol for 24-48 hours. The extracts were decanted and filtered with Whatman No.1 filter paper.

\section{3) Test Microorganisms}

In present study test microorganisms used for the antimicrobial screening were gram negative bacteria Escherichia coli and gram positive bacteria Bacillus subtilis clinical isolates were obtained from Department of Microbiology, Gujarat University, Ahmedabad, Gujarat, India.

\section{4) Culture Medium}

Nutrient agar (Hi-media) and nutrient broth were used for bacterial culture and potato dextrose agar (Hi-media) were used for plant pathogenic fungi in each experiment.

\section{5) Experimental Design}

For all experiments two replicates and control were kept duplicates and a control was kept. Medium was prepared by dissolving desired quantity of ingredients in distilled water. Both solid and liquid media used for the study were sterilized by autoclaving at $121^{\circ} \mathrm{C}, 15 \mathrm{lb}$ for 15 minutes and $\mathrm{pH}$ of the medium was set according by digital $\mathrm{pH}$ meter. Microbial inoculation was done with loop under aseptic condition of stericlean horizontal laminar air flow bench.

\section{6) Preparation of Extract of Different Concentration}

$2 \mathrm{mg}, 4 \mathrm{mg}, 6 \mathrm{mg}, 8 \mathrm{mg}, 10 \mathrm{mg}$ of crude extract was dissolved in $1 \mathrm{ml}$ of $50 \%$ of $\mathrm{N}$, N-Dimethyl sulfoxide DMSO.

\section{7) Antibacterial Activity}

In this method, $20 \mathrm{ml}$ of nutrient agar medium was poured in sterilized petri plates. And allow solidify at the room temperature. The flashy prepared $100 \mu \mathrm{l}$ or $0.1 \mathrm{ml}\left(1 \times 10^{6}\right.$ cells/ $\mathrm{ml}$ ) of organisms were spread with sterile L shaped bent glass rod. Using cork borer several wells of $6 \mathrm{~mm}$ in diameter were punched. The plates were incubated optimum growth condition for various organisms.

\section{Results}

\subsection{Phytochemical analysis of Allium cepa}

Results of phytochemicals present in crude petroleum ether, acetone and methanol extract of Allium cepa are given in Table. 1 As shown in table alkaloids, glycosides, tannins and carbohydrates are absent in petroleum ether extract. Acetone extract shows the presence of alkaloids flavonoids glycosides, steroids, phenols and volatile oils, amino acids, proteins triterpenoids and absence of tannins. Petroleum ether and acetone extract shows absence of tannin phenols, proteins, and glycosides. Methanol extract gave positive results for alkaloids flavonoids glycosides, steroids, tannins, phenols and volatile oils, amino acids, proteins and triterpenoids.

\subsection{Antibacterial activity of different extracts of Allium} cepa against Escherichia coli and Bacillus subtillis

The methanol extract of the Allium cepa had maximum zone of inhibition on Escherichia coli that $7.75 \pm 1.32 \mathrm{~mm}$ in 10 mg extract while minimum zone of inhibition found in petroleum ether that is $2.25 \pm 0.59 \mathrm{~mm}$ in $2 \mathrm{mg}$ extract. The methanol extract of the Allium cepa had high inhibition zone on Bacillus subtillis that is $7.25 \pm 0.59 \mathrm{~mm}$ in $10 \mathrm{mg}$. There was little or no zone inhibition of the acetone and petroleum ether extract on Bacillus subtillis whose zone of inhibition was not greater than 0-3.

\section{Tables}

Table 4.1: Phytochemical Screening of Different extract of Allium cepa

\begin{tabular}{|c|c|c|c|}
\hline \multirow{2}{*}{ Phytochemicals } & \multicolumn{3}{|c|}{ Extracts } \\
\cline { 2 - 4 } & Petroleum ether & Acetone & Methanol \\
\hline Alkaloids & $-\mathrm{ve}$ & $+\mathrm{ve}$ & $+\mathrm{ve}$ \\
\hline Amino acids \& protiens & $+\mathrm{ve}$ & $+\mathrm{ve}$ & $+\mathrm{ve}$ \\
\hline Carbohydrates & $-\mathrm{ve}$ & $+\mathrm{ve}$ & $+\mathrm{ve}$ \\
\hline Flavonoids & $+\mathrm{ve}$ & $+\mathrm{ve}$ & $+\mathrm{ve}$ \\
\hline Glycosides & $-\mathrm{ve}$ & $+\mathrm{ve}$ & $+\mathrm{ve}$ \\
\hline Steroids & $+\mathrm{ve}$ & $+\mathrm{ve}$ & $+\mathrm{ve}$ \\
\hline Triterpenoids & $+\mathrm{ve}$ & $+\mathrm{ve}$ & $+\mathrm{ve}$ \\
\hline Tannins & $-\mathrm{ve}$ & $-\mathrm{ve}$ & $+\mathrm{ve}$ \\
\hline Phenols & $+\mathrm{ve}$ & $+\mathrm{ve}$ & $+\mathrm{ve}$ \\
\hline
\end{tabular}

*-ve: Negetive, +ve: Positive

Table 4.2: Antibacterial activity Allium cepa of against Escherichia coli

\begin{tabular}{|c|c|c|c|c|c|c|}
\hline \multirow{2}{*}{ Ext } & \multicolumn{5}{|c|}{ Extract concentration $(\mathrm{mg} / \mathrm{ml})$} & \multirow{2}{*}{ CO } \\
\cline { 2 - 7 } & 2 & 4 & 6 & 8 & 10 & 10 \\
\hline PE & $2.25 \pm 0.59$ & $2.25 \pm 0.59$ & $3.25 \pm 0.59$ & $3.25 \pm 0.59$ & $3.5 \pm 0.84$ & 10 \\
\hline AC & 3 & $3.25 \pm 0.59$ & $3.75 \pm 0.59$ & $4.75 \pm 0.59$ & 5 & 11 \\
\hline ME & $4.25 \pm 0.59$ & $4.75 \pm 0.59$ & $5.75 \pm 0.59$ & $6.25 \pm 1.02$ & $7.75 \pm 1.32$ & 13 \\
\hline
\end{tabular}

$*$ Control Streptomycin $=10 \mu \mathrm{g} / \mathrm{ml}$, PE-Petroleum ether, ACAcetone, ME- Methanol, CO-Control

Table 4.3: Antibacterial activity of Allium cepa against Bacillus subtilis

\begin{tabular}{|c|c|c|c|c|c|c|}
\hline \multirow{2}{*}{ Ext } & \multicolumn{5}{|c|}{ Extract concentration $(\mathrm{mg} / \mathrm{ml})$} & \multirow{2}{*}{$\mathrm{CO}$} \\
\cline { 2 - 7 } & 2 & 4 & 6 & 8 & 10 & \\
\hline PE & $2.5 \pm 0.84$ & $2.75 \pm 0.59$ & $3.25 \pm 1.02$ & $4.25 \pm 0.59$ & $4.75 \pm 0.59$ & 10 \\
\hline AC & $2.75 \pm 1.02$ & $2.75 \pm 0.59$ & $3.25 \pm 1.02$ & $3.5 \pm 0.84$ & $4.5 \pm 1.45$ & 10 \\
\hline ME & $3.25 \pm 1.02$ & $3.5 \pm 0.84$ & $5.25 \pm 1.02$ & $6.25 \pm 1.02$ & $7.25 \pm 0.59$ & 12 \\
\hline
\end{tabular}

Control Streptomycin $=10 \mu \mathrm{g} / \mathrm{ml}$, PE-Petroleum ether, ACAcetone, ME- Methanol, CO-Control.

\section{Discussion}

\subsection{Phytochemical Analysis of Plant Extract}

In Table.4.1 it could be seen that, alkaloids, carbohydrates, glycosides and tannins are absent in all extract, except methanolic extracts. Flavonoids, steroids triterpenoids, tannins and phenolic compounds are present in onion extracts. 


\section{International Journal of Science and Research (IJSR) \\ ISSN (Online): 2319-7064 \\ Index Copernicus Value (2015): 78.96 | Impact Factor (2015): 6.391}

\subsection{Antimicrobial activity of Allium cepa}

In Table 4.2 and table 4.3, Allium cepa shows maximum inhibitory effect in methanolic extract against both stains Escherichia coli and Bacillus subtilis. The active principle is more soluble in methanol extract showed maximum activity against Escherichia coli and Bacillus subtilis.

Benkeblia et al., (2005) evalluates the antimicrobial activity of different phenolic compounds of three types of onions (Green, Yellow and Red)and garlic against two bacteria (Staphlococcus aureus and Salmonella enteritidis) and three fungi (Aspergillus niger, Penicillium cyclopim and Fusarium oxysporum). Garlic showed highest inhibition and green onion showed lowest inhibition. Fusaruim oxyspoaum shows highest sensitivity.

\section{Conclusion}

Qualitative phytochemical analysis conducted on the crude onion extract revealed the presence of phytochemicals which are known to exhibit medicinal as well as physiological activities. Thus it can be scientifically conclude that all these plants extracts could be seen as an increasingly valuable reservoir of bioactive compounds of substantial medicinal merit.

\section{Acknowledgements}

The author is thankful to Prof. Himamshu A Pandya of Department of Botany, Gujarat University, Ahmedabad (Gujarat) for his encouragement and for providing library and laboratory facilities during this investigation.

\section{References}

[1] B. K. Dash, S. Sultana and N. Sultana, "Antibacterial activities of methanol and acetone extracts of fenugreek (Trigonella foenum) and Coriander (Coriandrum sativum)," Life sciences and Medicine Research, Pp 1-8, 2011.

[2] D. F. Cornago, E. C. Amor, and W.L., Rivera, "Antifungal Activity of Onion (Allium cepa. L.) bulb extract against Fusarium oxysporum and Colletotrichum sp.," Philipp Agric Scientist, XCIV (1), pp 78-82, 2011.

[3] F. Nazzaro, G. Caliendo, G. Arnesi, A. Veronesia, P. Sarzi and F. Fratianni, "Comparative content of two varieties of Capsicum annum L. sweet papper and Evaluation of Their antimicrobial and mutagenic activities," J. food Biochem, XXXIII (6), pp 852-868, 2009.

[4] H. O. Edeoga, D. E Okwu and B. O. Mbaebie, "Phytochemical constituents of some Nigerian Medicinal Plants," African Journal of Biotechnology, IV (7) pp- 685-688, 2005.

[5] K. P. Sampathkumar, B. Debjiyt, Chiranjib, Biswajit, and P. Tiwari, "Allium cepa: A traditional medicinal herb and its health benefits," J.chem. Res, II (1), pp 283-291, 2010.

[6] J. Harborne (EDS), Phytochemical methods, A guide to modern techniqye of plant analysis, Champman and Hall, London, 1998.
[7] J. Mann, Secondary metabolism, Oxford, University Press, London, pp- 154, 1978

[8] K. Vasu, J. V. Goud, A. Suryam, and S. Chary, "Biomolecular and phytochemical analysis of three aquatic angiosperms," Afr. J. Microbiological. Res., III (8), pp 418-582, 2009

[9]N. Benkeblia, "Antimicrobial activity of essential oil extracts of various Onions (Allim cepa) and Garlic (Allium sativum)," Lebensm-Wiss-u-Technol, XXXVII, pp263-268. 2005.

[10]P. Namita and R. Mukesh, "Medicinal plant used as antimicrobial agents: A review," International Research Journal of Pharmacy, III (1) pp 31-40, 2012.

[11] R. D. Amarsingham, N. G. Bisset, A. H. Millard, and M. C. Woods, "A phytochemical survey of Malaya part III, Alkaloids and Saponins," Economic Botany, pp 270277. 1964

[12] R. D. Gibbs, Chemotaxonomy of flowering plants I-IV, University press, Moteral and London McGill Qyeens, 1974.

[13] R. Verpoorte, Chemodiversity and the Biological role of Secondary Metabolites, some thoughts for selecting plant material for drug development. Proc. Phytochem.Soc., Kluwer Publishers, Europe, XXXXIII, pp11-24, 2008

[14] S. C. Chhabra, F. C. Vsi, and E. N. Mishu, "Phyatochemical screening of Tanzanian medicinal plants,” Ind. J. Ethnopharmacol, XII, pp 157-159, 1984. 